\title{
NCl apologizes for fallout study delay
}

[WASHINGTON] The director of the US National Cancer Institute (NCI) admitted last week that his institute had been wrong to delay releasing the preliminary findings of a study of Americans' exposure to radioactive iodine from above-ground nuclear tests in the 1950s.

Under sharp questioning from the Senate appropriations subcommittee on Labor, Health and Human Services and Education, Richard Klausner said "a more clear, more rapid and more aggressive plan for dissemination of the results to the public was called for".

The "essential nature" of the study was complete three to four years ago, and at that point "there should have been a plan put in place to publicly disseminate the information", Klausner said. He became head of the NCI in 1995.

Congress in 1982 mandated the NCI to investigate the exposure of Americans to radioactive iodine during 90 above-ground nuclear tests at the Nevada Test Site in the

1950s. But it was only in August, under pressure from critics and the media, that the institute released a summary of its findings.

These suggested that up to 75,000 additional thyroid cancers may result from the tests, mainly in those who were young children at the time. Perhaps 70 per cent have yet to be diagnosed. The full report, running to more than 100,000 pages, was issued last week on the Internet ('what's new' at http:// www.nci.nih.gov or http://rex.nci.nih.gov).

The study did not address whether there is a definite link between thyroid cancer and internal exposure to radioactive iodine, mainly through ingestion of it in milk from cows. Instead it sought to establish the amount of radioactive iodine to which Americans on average were exposed. But Klausner said at last week's hearing that it is "very likely" that such exposure increases the risk of thyroid cancer.

Senator Tom Harkin (Democrat, Iowa), whose brother recently died of thyroid

\section{Gene-modified crop sabotaged in Ireland}

[DUBLIN] Ireland's first genetically modified crop has been sabotaged by a group of environmental activists styling themselves the Gaelic Earth Liberation Front. Police launched a criminal investigation into the destruction of a one-acre crop of genetically modified sugar beet, being grown under licence by US chemical company Monsanto on a state research farm in County Carlow, about 50 miles from Dublin.

The crop had been genetically modified to resist the company's herbicide Roundup, and a three-year trial had been approved by Ireland's Environmental Protection Agency, which insists there is no threat to the environment. But, despite the assurance, the project caused a storm of protest, with environmentalists staging demonstrations, mounting pickets and taking court action in an effort to stop it.

Six months ago, the Irish High Court finally gave Monsanto the go-ahead for the crop trials. But such was the level of protest that the company abandoned plans to conduct the trials at three separate Irish farms, using only the Carlow research farm.

In the attack, much of the almost mature beet was destroyed, and the rest dug up. The Gaelic Earth Liberation Front, a previously unknown group, said in a statement: "This was Ireland's first genetically engineered crop and we hope it will be the last."

Patricia McKenna, a Green Party member who represents Dublin in the European Parliament, praised those responsible, adding: "If Monsanto, which was carrying out the trials, and the
Environmental Protection Agency, which licensed them, insist on playing games with the Irish environment, then fair play to those who challenge them through peaceful direct action."

Monsanto described her comment as "extraordinary, given that this was an illegal act". It said it was "shocked and dismayed at this act of wanton damage", and accused those responsible of having no interest in scientific research or the benefits it could bring. Monsanto intends to resume the trials as soon as possible.

A spokesman for Genetic Concern, an Irish environmentalist lobby which led the opposition, denied any involvement in the sabotage, or knowledge of the new group. But he added: "We're not surprised. There are a lot of people very annoyed the tests went ahead without adequate public debate."

Anthony Garvey

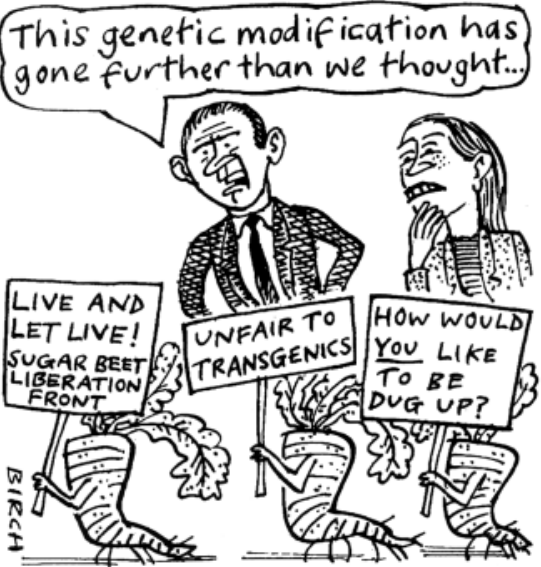

cancer, who himself has thyroid nodules and who comes from an area that was highly exposed to the fallout, demanded to know why the study had taken almost 15 years to complete.

Klausner said that the study's length "overwhelmingly" reflected its complexity, and pointed to interim reports to Congress in 1984, 1986 and 1991, as well as open public meetings of an external advisory panel, as evidence that the institute was not trying to cover anything up.

Revealingly, a written chronology of the study's progress distributed by the NCI included comments made in 1993 such as "major part of database unintelligible to all but programmer" and "mapping software deleted after computer crash". It also said that the average dose to Americans from all 90 tests — 2 rads — was established in 1994.

Critics said NCI was negligent in not releasing those results immediately. "Onceagain, people feel like nuclear age guinea pigs or mere statistics - as though the government has infinitely more interest in studying them than in helping them," said Tim Connor, associate director of the Energy Research Foundation, who testified at the hearing.

Another critic, Joseph Lyon, a professor of family medicine at the University of Utah, suggested he had been effectively blocked by Bruce Wachholz, the study's overseer and chief of NCI's Radiation Effects Branch, from obtaining funding to follow up a study that found a threefold excess of thyroid cancer in subjects exposed as children to fallout from the tests. "The message came back: this is of no scientific interest," said Lyon.

Klausner denied that the NCI was not interested in follow-up studies, and said the denial of funding would have been the result of a failure to meet required standards of peer review. But Arlen Specter (Republican, Pennsylvania), the subcommittee chairman, said that the panel intended to pursue the matter. "These are very serious charges about this administration of NCI being... not up to doing this job," he said.

The NCI has now commissioned the Institute of Medicine to produce two reports determining the soundness of the NCI study's dose estimates, assigning risks of health consequences, and recommending public health measures. Both are due in the first half of 1998.

But their conclusions may come too late to avoid the damage to NCI's reputation. "The ground that's lost when, fairly or unfairly, a federal agency is perceived to be withholding information can be devastating," said Ruth Faden, director of the Johns Hopkins Bioethics Institute, who chaired the President's Advisory Committee on Human Radiation Experiments. MeredithWadman 